Revista Brasil. Bot., V.32, n.1, p.11-21, jan.-mar. 2009

\title{
Morphometric analysis of the Brasiliorchis picta complex (Orchidaceae)
}

\author{
FÁBIO PINHEIRO ${ }^{1}$ and FÁBIO DE BARROS ${ }^{1,2}$
}

(received: February 08, 2007; accepted: November 06, 2008)

\begin{abstract}
Morphometric analysis of the Brasiliorchis picta complex (Orchidaceae)). One of the largest genera of Orchidaceae in the Neotropics with about 450 species, Maxillaria presents several taxonomic uncertainties about its generic circumscription and the delimitation of species groups, mainly due to the large variability of some species. The present study aims at verifying the morphological variation and species delimitation in the Brasiliorchis picta complex, a recent new genus derived from Maxillaria, using morphometric multivariate analysis. A total of 340 specimens belonging to six species (B. chrysantha (Barb. Rodr.) R.B. Singer, S. Koehler \& Carnevali, B. gracilis (Lodd.) R.B. Singer, S. Koehler \& Carnevali, B. marginata (Lindl.) R.B. Singer, S. Koehler \& Carnevali, B. picta (Hook.) R. Singer, S. Koehler \& Carnevali, B. porphyrostele (Rchb. f.) R.B. Singer, S. Koehler \& Carnevali and B. ubatubana (Hoehne) R.B. Singer, S. Koehler \& Carnevali) were analyzed using multivariate methods (PCA, CVA, DA, and Cluster Analysis with UPGMA). B. gracilis shows the largest morphological discontinuity, mainly due to its smaller size. The other species tend to form distinct groups, but intermediate characteristics between pairs of species induce overlaps among the individuals of different species and thus confuse the distinction of each one. Hybridization and geographic distribution can be involved in the differentiation of the species and lineages in this complex. Because the species classified a priori in this work cannot be recognized by the quantitative characters measured here, such other tools as geometric morphometry and molecular data should be employed in future works to clarify species relationships in this complex.
\end{abstract}

Key words - morphometry, multivariate analysis, species complex, taxonomy

RESUMO - (Análise morfométrica do complexo Brasiliorchis picta (Orchidaceae)). Maxillaria é um dos maiores gêneros da região Neotropical com cerca de 450 espécies, apresentando diversas incertezas taxonômicas quanto à delimitação do gênero e de diversas espécies, principalmente pela grande variação morfológica que o grupo apresenta. Este trabalho tem por objetivo analisar a variação morfológica e a delimitação de algumas espécies no complexo Brasiliorchis picta, um gênero criado recentemente a partir de algumas espécies de Maxillaria, utilizando análise multivariada morfométrica. Foram analisados 340 indivíduos, distribuídos em seis espécies (B. chrysantha (Barb. Rodr.) R.B. Singer, S. Koehler \& Carnevali, B. gracilis (Lodd.) R.B. Singer, S. Koehler \& Carnevali, B. marginata (Lindl.) R.B. Singer, S. Koehler \& Carnevali, B. picta (Hook.) R. Singer, S. Koehler \& Carnevali, B. porphyrostele (Rchb. f.) R.B. Singer, S. Koehler \& Carnevali e B. ubatubana (Hoehne) R.B. Singer, S. Koehler \& Carnevali), empregando-se métodos de análise multivariada (PCA, CVA, DA e UPGMA). Brasiliorchis gracilis exibiu as maiores descontinuidades morfológicas, relacionadas principalmente ao seu porte reduzido. Entre as demais espécies, é possível notar apenas tendências de agrupamento, nas quais um grande número de caracteres com valores intermediários gera grande sobreposição entre indivíduos de diferentes espécies, não permitindo uma clara separação entre as espécies. Os padrões de distribuição geográfica e eventos como hibridização podem estar envolvidos na diferenciação de espécies e linhagens no complexo. Como as espécies classificadas a priori neste trabalho não podem ser reconhecidas através dos caracteres quantitativos utilizados, outras técnicas como morfometria geométrica e dados moleculares devem ser empregados em trabalhos futuros para esclarecer as relações de parentesco entre as espécies deste complexo.

Palavras-chave - análise multivariada, complexo de espécies, morfometria, taxonomia

\section{Introduction}

Maxillaria Ruiz \& Pavón s.l. belongs to the subfamily Epidendroideae, tribe Maxillarieae, subtribe Maxillariinae (Dressler 1993). It is the largest genus of this subtribe, with about 450 species (Atwood \& Mora-de-Retana 1999) distributed only in the Neotropics. According to Pabst \& Dungs (1977), 94 species of the genus occur in Brazil. Because of the large morphological diversity of this genus,

1. Instituto de Botânica, Caixa Postal 3005, 01061-970 São Paulo, SP, Brazil.

2._Corresponding author: fdebarros@terra.com.br its delimitation has become a controversial issue: Cogniaux (1904-1906), Hoehne (1953) and Butzin \& Senghas (1996) consider Camaridium Lindl., Marsupiaria Hoehne, Ornithidium Salisb., and Pseudomaxillaria Hoehne as valid genera, segregated from Maxillaria mainly due to the structural variation of their vegetative characters. Conversely, Dunsterville \& Garay (1961), Pabst \& Dungs (1977) and Atwood \& Mora-de-Retana (1999) place these genera within Maxillaria, possibly because they consider that the large variability of their vegetative structures is due to the wide geographic distribution of the group, which can be found from Florida to Argentina, as epiphytes or rupicolous (Holtzmeier et al. 1998). 
Anatomical data revealed that Maxillaria is polyphyletic if Mormolyca Fenzl. is considered (Holtzmeier et al. 1998). Dathe \& Dietrich (2006) and Whitten et al. (2007), whose sampling included different species of Maxillaria and such closely related genera as Camaridium Lindl., Ornithidium Saliob. ex R. Br., Trigonidium Lindl., Chrysocycnis Linden \& Rchb.f., Cryptocentrum Benth., and Mormolyca, obtained a phylogeny based on molecular data and their results point out that Maxillaria is paraphyletic if these genera are maintained. Those studies supports a Maxillaria genus with a more restricted delimitation, and the recognition of some allied genera, many of them recently created based on phylogenetic results, such as Brasiliorchis R. Singer, S. Koehler \& Carnevali (Singer et al. 2007), Christensonella Szlach., Mytnik, Górniak \& Smiszek (Szlachetko et al. 2006) and Sauvetrea Szlach. (Szlachetko \& Smiszek 2007). Taxonomic problems are common in the delimitation of species in Maxillaria s.l., as shown in the works by Illg (1977) on the section Heterotaxis, Onishi (1974) on the Maxillaria madida complex and Carnevali et al. (2001) on the Maxillaria rufescens complex.

The species of Maxillaria were divided in to 11 groups in the taxonomic treatment of Butzin \& Senghas (1996). Group XI, which encompasses species with pseudobulbs in "cushion" form, joined by a short rhizome, was subdivided into three subgroups. One of these subgroups, the so called Maxillaria picta complex, in which most species have bifoliate pseudobulbs and occur exclusively in Brazil, is known by its extensive morphological variation, which entails several problems to delimit its species. Anatomical (Holtzmeier et al. 1998) and molecular (Dathe \& Dietrich 2006, Whitten et al. 2007) data show a monophyletic group which includes the species of this complex, and occurs only in Brazilian atlantic and seasonal deciduous forests. This group was recently transferred for the genus Brasiliorchis (Singer et al. 2007), and here we adopt this criterion.

Many specific names are associated to this complex and it is not possible to delimit the species objectively, because of the high morphological variation (Hoehne 1953, Pabst \& Dungs 1977). In this group, flowers have many colour patterns, even in a single population, mainly among the species with spotted sepals and petals, such as B. picta (Hook.) R. Singer, S. Koehler \& Carnevali and B. ubatubana (Hoehne) R. Singer, S. Koehler \& Carnevali, which can exhibit several pigmentation degrees (Hoehne 1953). Flower morphology is also variable in size and form, making species identification quite difficult.

Although Hoehne (1953) considered 15 species and 19 varieties in the Brasiliorchis picta complex, he admits that mistakes may exist in species delimitation because of the large variations and that a large amount of collections needs to be investigated. Most varieties described by Hoehne $(1952,1953)$ illustrate specimens that present continuous morphological characteristics with no striking discontinuities. Pabst \& Dungs (1977) have accepted most of the classification proposed by Hoehne (1953), but, based on vegetative characteristics, they split these species in three "alliances": "picta alliance", "marginata alliance" and "gracilis alliance". Butzin \& Senghas (1956) join together the "picta" and "gracilis" alliances of Pabst \& Dungs (1977) and keep the "marginata" alliance as a different group.

This study aims at describing the morphological variation present in the B. picta complex using quantitative characters and multivariate analysis methods to identify patterns of variation, determining the characters related to these patterns, and explaining the species relationships within this complex.

\section{Material and methods}

A total of 340 living plants from 30 Brazilian localities were studied (table 1). The specimens were grown for at least 20 years at the "Instituto de Botânica" at São Paulo (Brazil), so that the influence of habitat conditions was minimized.

Because species recognition is complex, a broad delimitation was adopted, and the specimens were previously identified based on qualitative characters observed in living plants (table 2). The names used herein have been commonly employed in the taxonomic literature on this group (Hoehne 1953, Pabst \& Dungs 1977, Butzin \& Senghas 1996) and have nomenclatural priority over recent names avoided here. The specimens were split in six species (table 2). Line drawings of dissected flowers from representative specimens of these six species were made to show the morphological variation among and within species (figure 1). Because Brasiliorchis consanguinea (Klotzsch) R.B. Singer, S. Koehler \& Carnevali, B. heismanniana (Barb. Rodr.) R.B. Singer, S. Koehler \& Carnevali, B. kautskyi (Pabst) R.B. Singer, S. Koehler \& Carnevali, and B. schunkeana (Campacci \& Kautsky) R.B. Singer, S. Koehler \& Carnevali are rare species whose morphological characters differ considerably from those of the individuals measured in this work and since no living material was available, they were not included.

Twenty continuous morphological characters were measured (table 3), four of which are vegetative and 16 floral (figure 1). All measurements of any of the considered character were taken at the point of maximum dimension. Three flowers for each specimen are measured, and the mean value among them was considered in the analysis. Figure 1 presents details of floral characters. Vouchers of representative individuals of each species and each population are deposited at the herbarium SP (table 1). 
Table 1. Procedence, number of specimens analyzed and vouchers for each species. Vouchers were made from one specimen per population and are deposited in Herbarium SP (Institute of Botany, São Paulo State, Brazil). (BA = Bahia; ES = Espírito Santo; MG = Minas Gerais; PR = Paraná; RJ = Rio de Janeiro; SC = Santa Catarina; SP = São Paulo states).

\begin{tabular}{|c|c|c|}
\hline Species/Origin & $n$ & Voucher \\
\hline \multicolumn{3}{|l|}{ B. gracilis } \\
\hline Santana do Riacho - MG & 27 & H.D. Bicalho s.n. (SP373874) \\
\hline \multicolumn{3}{|l|}{ B. chrysantha } \\
\hline Mucuri - BA & 2 & F. Pinheiro 407 \\
\hline Teófilo Otoni - MG & 7 & F. Pinheiro 319 \\
\hline São Tomé das Letras - MG & 3 & F. Pinheiro 411 \\
\hline Linhares - ES & 4 & F. Pinheiro 372 \\
\hline Guaíra - PR & 5 & F. Pinheiro 397 \\
\hline \multicolumn{3}{|l|}{ B. marginata } \\
\hline São Paulo - SP & 12 & F. Pinheiro 277 \\
\hline Blumenau - SC & 15 & F. Pinheiro 419 \\
\hline Orleans - SC & 6 & F. Pinheiro 419 \\
\hline \multicolumn{3}{|l|}{ B. picta } \\
\hline Jacinto - MG & 9 & F. Pinheiro 415 \\
\hline Caldas - MG & 23 & F. Pinheiro 416 \\
\hline Parati - RJ & 9 & F. Pinheiro 305 \\
\hline Ubatuba - SP & 27 & F. Pinheiro 285 \\
\hline Atibaia - SP & 14 & F. Pinheiro 317 \\
\hline Salesópolis - SP & 13 & F. Pinheiro 417 \\
\hline Peruíbe - SP & 8 & F. Pinheiro 293 \\
\hline Cananéia - SP & 15 & F. Pinheiro 279 \\
\hline Jacupiranga - SP & 20 & F. Pinheiro 332 \\
\hline Batatais - SP & 13 & F. Pinheiro 418 \\
\hline Jaguariaiva - PR & 28 & F. Pinheiro 386 \\
\hline \multicolumn{3}{|l|}{ B. porphyrostele } \\
\hline Teodoro Sampaio - SP & 8 & F. Pinheiro 345 \\
\hline Matos Costa - SC & 15 & F. Pinheiro 331 \\
\hline Lages - SC & 8 & F. Pinheiro 358 \\
\hline Bom Jardim da Serra - SC & 5 & F. Pinheiro 364 \\
\hline São Joaquim - SC & 4 & F. Pinheiro 367 \\
\hline \multicolumn{3}{|l|}{ B. ubatubana } \\
\hline Itagimirim - BA & 10 & F. Pinheiro 342 \\
\hline Camanducaia - MG & 5 & F. Pinheiro 343 \\
\hline Petrópolis - RJ & 3 & F. Pinheiro 294 \\
\hline Campos do Jordão - SP & 10 & F. Pinheiro 356 \\
\hline Apiaí - SP & 8 & F. Pinheiro 339 \\
\hline
\end{tabular}

The descriptive analysis of the data was performed with SYSTAT 10.0 (Wilkinson 2000) software and presented graphically as box plots. Multivariate analysis methods were carried out with the programs SYSTAT 10 and Fitopac 1.6 (Shepherd 2006) softwares. Two types of ordination analysis and one cluster method were used to avoid possible distortions produced by a specific method (Everitt 1978): principal component analysis (PCA) on a correlation matrix was used as an objective method to summarize variation when a priori knowledge of population to which individuals belonged was not considered; canonical variate analysis (CVA) was used to ordinate population means considering variance and covariance among characters within and among populations; and a cluster analysis was performed using the unweighted pair group method with arithmetic average (UPGMA), on an Euclidean distance matrix, to verify morphological discontinuities among species. Twenty plants of each species were randomly chosen from the total sample and analysed with the UPGMA method to improve the graphical representation of the dendrogram. In PCA, the number of 
Table 2. Qualitative characters used to delimit the six species considered in this study. Species names considered synonyms are between parentheses.

\begin{tabular}{|c|c|}
\hline Species & Qualitative characters \\
\hline $\begin{array}{l}\text { Brasiliorchis chrysantha (Barb. Rodr.) } \\
\text { R.B. Singer, S. Koehler \& Carnevali }\end{array}$ & $\begin{array}{l}\text { Long rhizome, sepals and petals with vinaceous margins, vinaceous column, } \\
\text { lip white with vinaceous spots. }\end{array}$ \\
\hline $\begin{array}{l}\text { Brasiliorchis gracilis (Lodd.) } \\
\quad \text { R.B. Singer, S. Koehler \& Carnevali }\end{array}$ & $\begin{array}{l}\text { Aggregated rhizomes, lip white with vinaceous spots, column pale yellow } \\
\text { with vinaceous dashes. }\end{array}$ \\
\hline $\begin{array}{l}\text { Brasiliorchis marginata (Lindl.) } \\
\text { R.B. Singer, S. Koehler \& Carnevali } \\
\text { (Maxillaria murilliana Hoehne) } \\
\text { (M. crassipes Kraenzl.) }\end{array}$ & $\begin{array}{l}\text { Long rhizome, lip pale yellow with central and lateral lobe apex dark purple, } \\
\text { column yellow with vinaceous dashes. }\end{array}$ \\
\hline $\begin{array}{l}\text { Brasiliorchis picta (Hook.) } \\
\text { R. Singer, S. Koehler \& Carnevali } \\
\text { (Maxillaria rupestris Barb. Rodr.) } \\
\text { (M. phoenicanthera Barb. Rodr.) } \\
\text { (M. polyantha Barb. Rodr.) } \\
\text { (M. hoehnei } \text { Schltr.) }\end{array}$ & $\begin{array}{l}\text { Aggregated rhizomes, sepals and petals with abaxial face pale yellow, adaxial } \\
\text { face yellow, white lip with vinaceous dots, column yellow with vinaceous } \\
\text { dashes, purple anther. }\end{array}$ \\
\hline $\begin{array}{l}\text { Brasiliorchis porphyrostele (Rchb. f.) } \\
\text { R.B. Singer, S. Koehler \& Carnevali }\end{array}$ & $\begin{array}{l}\text { Aggregated rhizomes, sepals and petals yellowy green with vinaceous } \\
\text { margins, lip white with vinaceous dots, column vinaceous. }\end{array}$ \\
\hline $\begin{array}{l}\text { Brasiliorchis ubatubana (Hoehne) } \\
\text { R.B. Singer, S. Koehler \& Carnevali }\end{array}$ & $\begin{array}{l}\text { Aggregated rhizomes, pale yellow flowers with vinaceous dots, lip white } \\
\text { with vinaceous dots, column vinaceous. }\end{array}$ \\
\hline
\end{tabular}

Table 3. Morphological characters used in morphometric analyses of B. picta complex and results of principal component analysis (PC1, PC2 and PC3), canonical variate analysis (CN1, CN2 and CN3) and discriminant analysis (F-to-remove). PC1-PC2: correlations between the original variables with principal components one and two, respectively; CN1-CN2: correlations between the original variables and canonical discriminant axes one and two, respectively; F-to-remove: relative importance of the variables used in the model to discriminate groups in DA (see table 5).

\begin{tabular}{|c|c|c|c|c|c|c|c|c|}
\hline Characters & Code & PC1 & PC2 & PC3 & CN1 & $\mathrm{CN} 2$ & CN3 & F-to-remove \\
\hline 1. Rhizome length & RI_L & -0.203 & 0.347 & 0.704 & 0.217 & 0.455 & 0.422 & 32.57 \\
\hline 2. Pseudobulb length & PS_L & 0.408 & 0.690 & 0.078 & -0.089 & 0.178 & -0.086 & 4.49 \\
\hline 3. Leaf length & LE_L & 0.524 & 0.279 & -0.510 & 0.297 & -0.362 & -0.180 & 9.22 \\
\hline 4. Leaf width & LE_W & 0.436 & 0.524 & 0.265 & -0.033 & 0.237 & 0.040 & 12.6 \\
\hline 5. Inflorescence length & IN_L & 0.507 & 0.659 & -0.107 & 0.034 & 0.270 & 0.122 & 1.93 \\
\hline 6. Pedicel length & PE_L & 0.237 & 0.623 & 0.278 & -0.292 & 0.119 & 0.242 & 5.75 \\
\hline 7. Column length & CO_L & 0.796 & -0.236 & 0.367 & -0.387 & -0.009 & 0.132 & 3.21 \\
\hline 8. Column width & CO_W & 0.905 & 0.013 & 0.147 & 0.420 & 0.015 & 0.291 & 8.51 \\
\hline 9. Dorsal sepal length & DS_L & 0.877 & 0.085 & -0.284 & 0.628 & 0.356 & 0.007 & 2.73 \\
\hline 10. Dorsal sepal width & DS_W & 0.891 & 0.019 & -0.039 & -0.012 & 0.097 & -0.058 & 5.67 \\
\hline 11. Lateral sepal length & LS_L & 0.880 & 0.128 & -0.300 & -0.004 & -0.296 & -0.282 & 1.51 \\
\hline 12. Lateral sepal width & LS_W & 0.880 & -0.021 & 0.021 & -0.138 & 0.112 & 0.099 & 1.35 \\
\hline 13. Petal length & PT_L & 0.891 & -0.002 & -0.268 & 0.094 & 0.302 & -0.566 & 3.43 \\
\hline 14. Petal width & PT_W & 0.848 & 0.123 & -0.181 & 0.170 & -0.023 & -0.386 & 5.08 \\
\hline 15. Lip length & LI_L & 0.900 & -0.225 & 0.124 & 0.088 & -0.108 & 0.251 & 1.25 \\
\hline 16. Lip width & LI_W & 0.817 & -0.329 & 0.282 & 0.397 & -0.098 & 0.834 & 10.37 \\
\hline 17. Lateral lobe of lip length & LL_L & 0.877 & -0.185 & 0.294 & 0.372 & 0.438 & -0.113 & 3.16 \\
\hline 18. Central lobe of lip length & CL_L & 0.662 & -0.195 & -0.158 & -0.667 & -0.200 & 0.230 & 9.52 \\
\hline 19. Central lobe of lip width & CL_W & 0.741 & -0.413 & 0.148 & -0.406 & -0.948 & -0.185 & 17.91 \\
\hline 20. Callus of lip length & CA_L & 0.857 & -0.129 & 0.168 & 0.226 & -0.291 & 0.004 & 3.03 \\
\hline
\end{tabular}



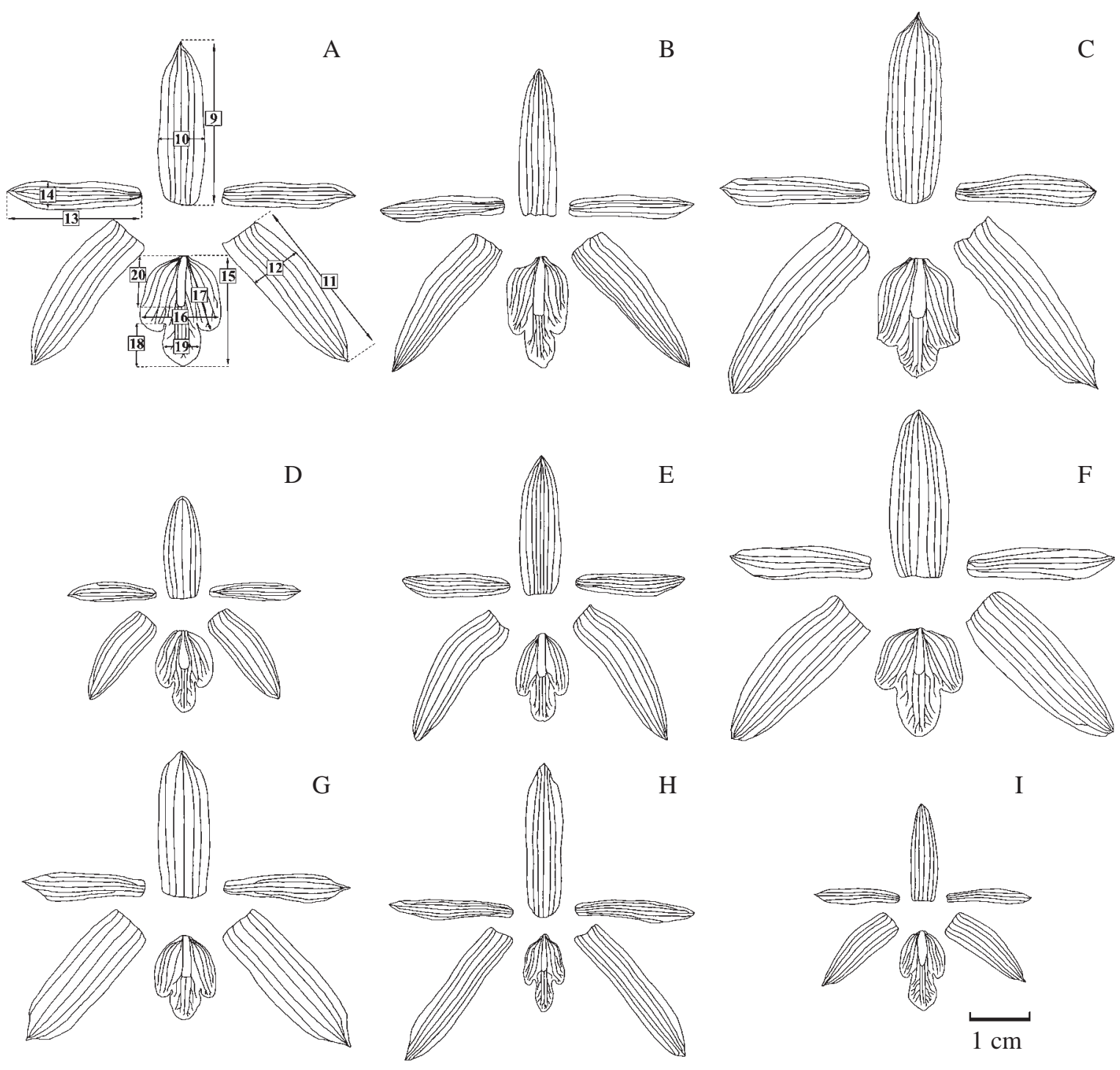

Figure 1. Line drawings of dissected flowers showing the morphological variation among and within the six species from Brasiliorchis picta complex. Vouchers of each flower are deposited at the herbarium SP. A. B. chrysantha (F. Pinheiro 294). B. B. chrysantha (F. Pinheiro 288). C. B. ubatubana (F. Pinheiro 385). D. B. marginata (F. Pinheiro 9261). E. B. marginata (F. Pinheiro 10438). F. B. porphyrostele (F. Pinheiro 328). G. B. picta (F. Pinheiro 320). H. B. picta (F. Pinheiro 341). I. B. gracilis (H.D. Bicalho s.n. SP373874). Details of measurements can be seen in A.

axes to interpret was determined by comparing eigenvalues to the random expectation in a broken-stick distribution (Frontier 1976). The six species were the grouping variables in CVA. Discriminant analysis (DA) was performed with the same grouping variables used in CVA. Wilks' Lambda, jackknife classification, which assigns unclassified specimens to groups, and F-to remove statistics, which give an indication of the relative importance of each variable, are also reported.

\section{Results}

The results of the descriptive analysis show that most characters overlap among the species (figure 2).
Brasiliorchis gracilis (Lodd.) R.B. Singer, S. Koehler \& Carnevali is the species with lesser overlaping with the others. Asterisks (outside values) and circles (far outside values) are present in most box plots, showing specimens with extreme values in all species.

In PCA, the first three axes explain about $74 \%$ of the total variation (figure 3 ). The species show only a tendency to differentiation in the analysis, since individuals of different species are spread in many parts of the scatter plot, making the delimitation of patterns difficult. On the first axis, that explain $55.14 \%$ of the total variation, individuals of $B$. gracilis, $B$. porphyrostele 

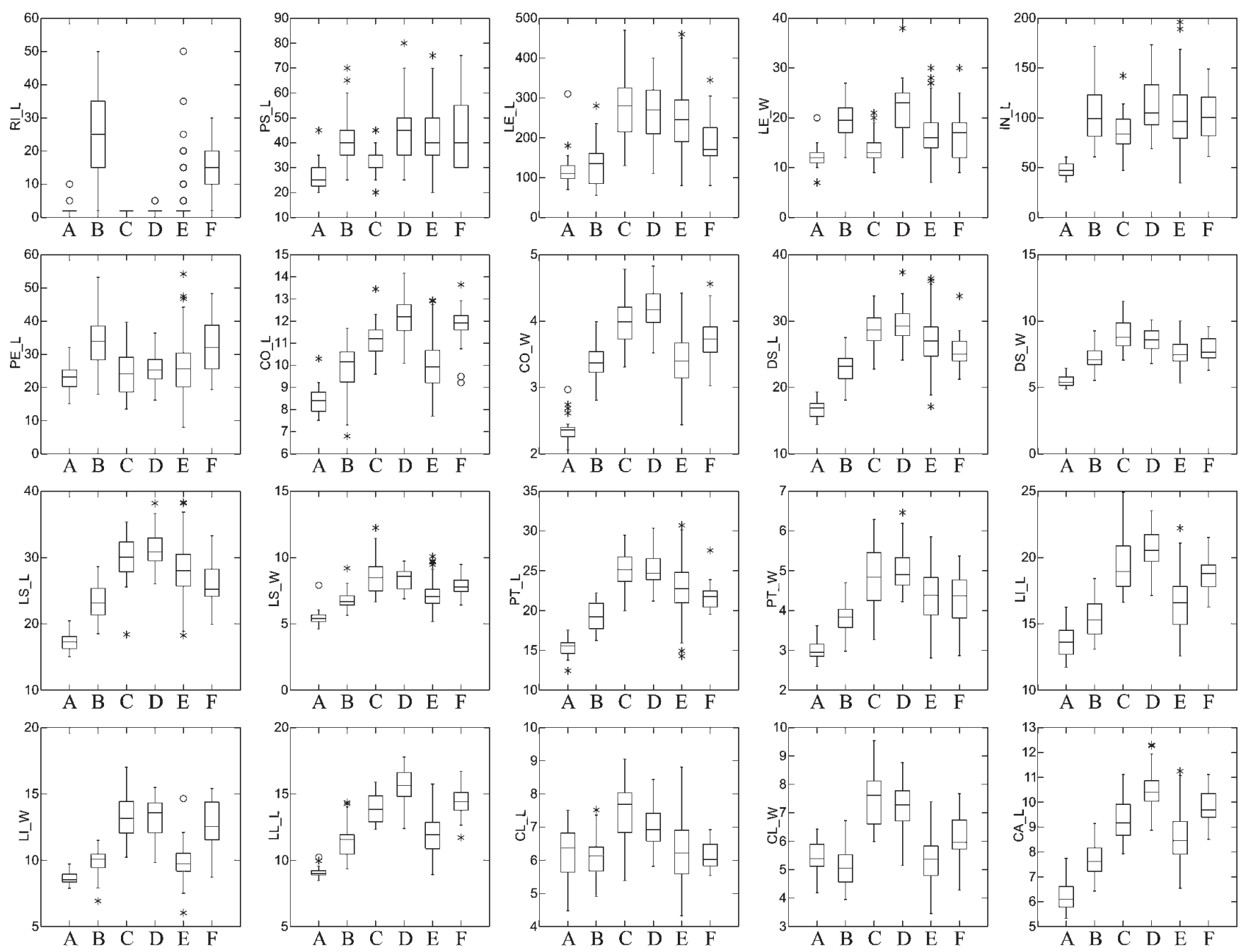

Figure 2. Box plots for the 20 quantitative characters. Rectangles define 25 and 75 percentiles; horizontal lines show median; whiskers are from 10 to 90 percentiles; asterisks and circles are extreme values. See table 4 for characters abbreviation. A. B. gracilis. B. B. marginata. C. B. porphyrostele. D. B. ubatubana. E. B. picta. F. B. chrysantha.

(Rchb. f.) R.B. Singer, S. Koehler \& Carnevali and $B$. ubatubana (Hoehne) R.B. Singer, S. Koehler \& Carnevali can be discriminated from the others. In the axis two, that explain $11.42 \%$ of the total variation, the majority of the individuals from $B$. ubatubana can be separated from $B$. porphyrostele. In this axis, $B$. marginata show a tendency to separate from the other species, but this pattern is best seen in axis three, where most of the individuals of this species are kept more apart from the others. The scatter plot with axes one and three show also a differentiation between specimens of B. marginata (Lindl.) R.B. Singer, S. Koehler \& Carnevali and B. chrysantha (Barb. Rodr.) R.B. Singer, S. Koehler \& Carnevali. Specimens of B. picta are spread along the three axes, showing no tendencies to split from the other species (figure 3). Flower characters are correlated with axis one, and vegetative characters are more correlated with axes two and three. CO_W, LI_L, DS_W, PT_L, and LS_W are the five most important characters correlated with the first axis. PS_L, IN_L, PE_L, LE_W and RI_L are the five most important characters correlated with the second. Otherwise, RI_L, CO_L, LL_L, LI_W and PE_L are the five most important characters correlated with the third axis (see table 3 for abbreviations).

The first three axes in CVA explain about $86 \%$ of the total variation (figure 4). The first axis explain 39.1\% of the total variation, and clearly separates specimens of B. gracilis from the other species. Specimens of B. ubatubana appear together in the analysis, showing 

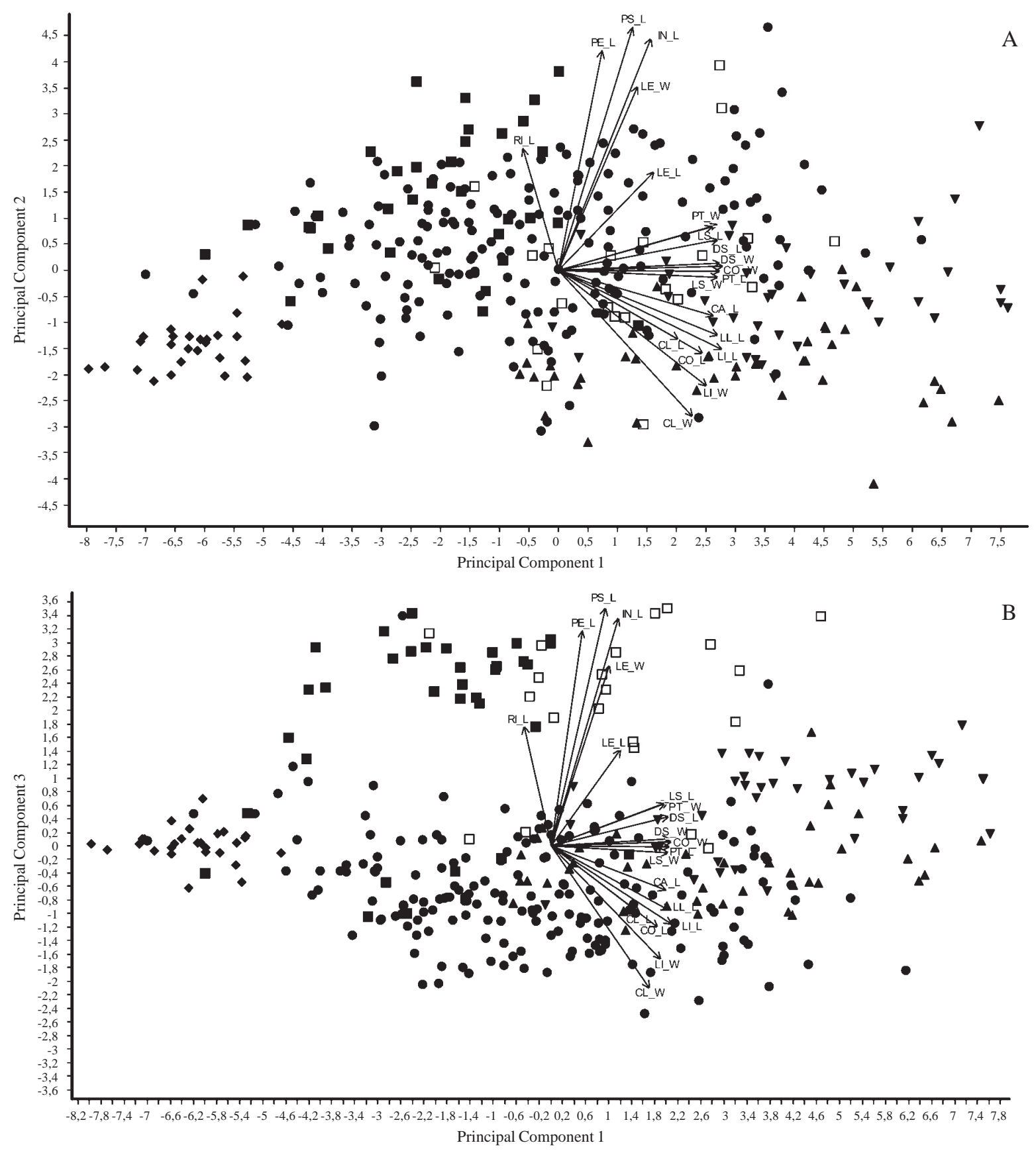

Figure 3. PCA of 340 specimens from the B. picta complex based on 20 characters (see table 3 ). A. Principal components 1 and 2. B. Principal components 1 and 3. Axes 1, 2 and 3 explain 55.14\%, 11.42\%, and $8.04 \%$ of the total variation, respectively. $(\forall=$ B. gracilis; $\boldsymbol{\square}=$ B. marginata $; \boldsymbol{\Lambda}=$ B. porphyrostele $; \boldsymbol{\nabla}=$ B. ubatubana $; \bullet=$. picta; $\square=$ B. chrysantha $)$.

also a tendency to separate from the other species. The second axis explains $26.7 \%$ of the total variation, and allows the discrimination of specimens of $B$. porphyrostele and $B$. marginata, both in the extremes of the scatter plot with axes one and two (figure 4A). The third axis explains $21.1 \%$ of the total variation and shows a more clear separation of B. marginata and B. chrysantha.
Most of the specimens of B. picta show a tendency to separate from the other species in the third axis, nevertheless they show some overlap with individuals of different species (figure 4B). CL-L, DS-L, CO-W, CL-W and LI-W are the five most important characters related to the first axis. RI_L, LL_L, DS_L, PT_L and IN_L are the five most important characters related to 

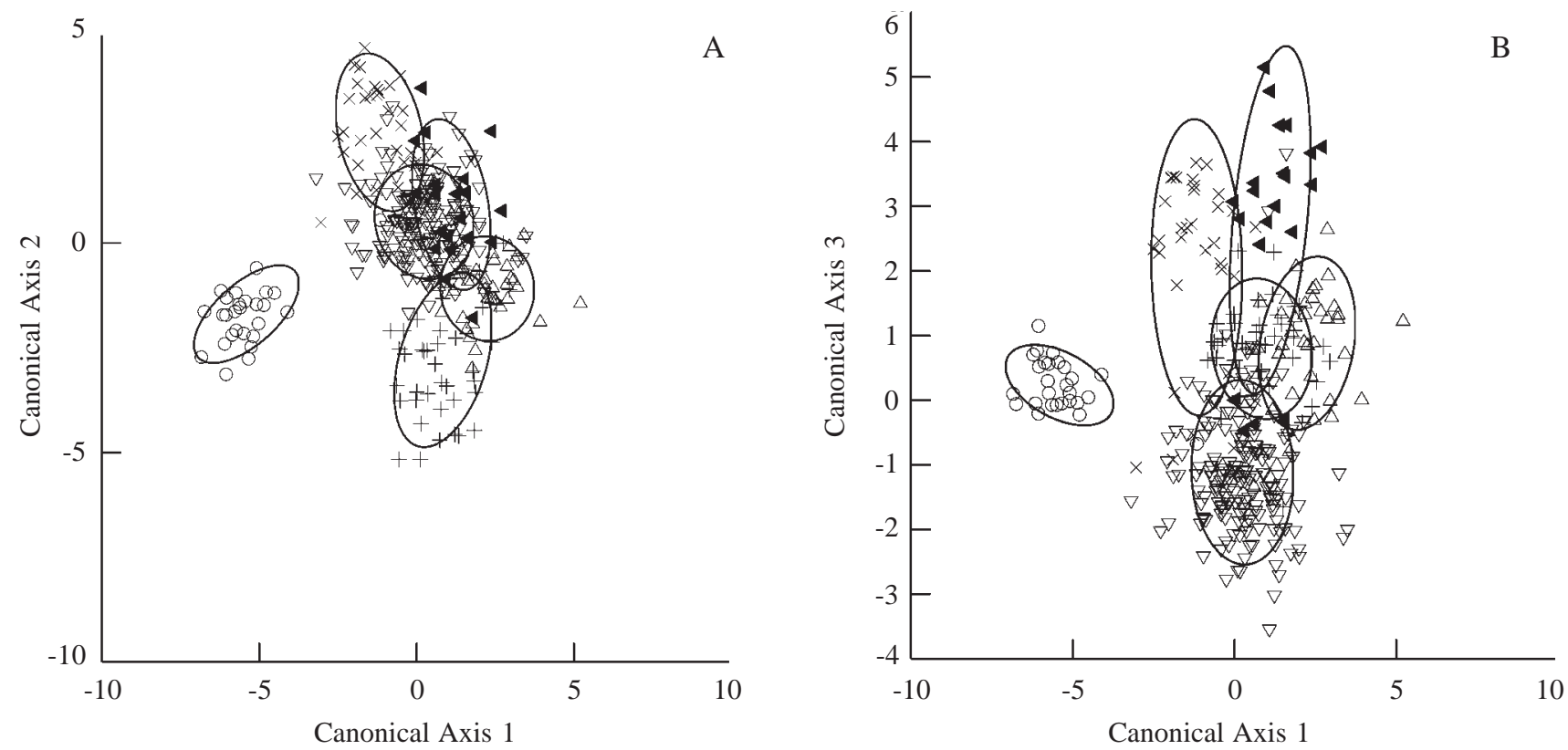

Figure 4. CVA of 340 specimens from the B. picta complex based on 20 characters (see table 3 ). Grouping variables are the six species considered in this study: B. chrysantha, B. gracilis, B. marginata, B. picta, B. porphyrostele, and B. ubatubana. Axes 1,2 and 3 explains $39.1 \%, 26.7 \%$ and $21.1 \%$ of the total variation, respectively. The ellipses are centered on the sample means, and comprises $70 \%$ of the sample from each species. $(\mathrm{O}=$ B. gracilis; $\mathbf{X}=B$. marginata $;+\boldsymbol{+}$. porphyrostele; $\Delta=$ B. ubatubana $; \nabla=$ B. picta $; \triangleleft=$ B. chrysantha $)$.

the second axis and LI_W, RI_L, CO_W, LI_L and PE_L are the five most important characters related to the third axis.

The jackknifed classification matrix produced by DA shows $85 \%$ of correct classification of the individuals into the previously assigned species (table 4). Brasiliorchis gracilis showed the highest percentage of correct classification (96\%), with one individual being misclassified as B. picta. Brasiliorchis chrysantha showed the lowest percentage of correct classification (67\%), sharing misclassified specimens with B. picta (4), B. marginata (2) and B. porphyrostele (1). Brasiliorchis marginata and B. picta, despite the high percentages of correct classification ( $74 \%$ and $89 \%$ respectively), have misclassified specimens into five other different species. Brasiliorchis porphyrostele and B. ubatubana showed $80 \%$ and $84 \%$ of correct classification, but have misclassified specimens into two and three other different species, respectively. A high level of morphological similarity can be noted between B. ubatubana and B. porphyrostele.

Table 4. Results of jackknifed classification matrix with 340 individuals and six species. (Wilks' Lambda $=0.011, P=$ $0.0000)$.

\begin{tabular}{lccccccc}
\hline Grouping variables & $\begin{array}{c}B . \\
\text { gracilis }\end{array}$ & $\begin{array}{c}B . \\
\text { marginata }\end{array}$ & $\begin{array}{c}B . \\
\text { porphyrostele }\end{array}$ & $\begin{array}{c}B . \\
\text { ubatubana }\end{array}$ & $\begin{array}{c}B . \\
\text { picta }\end{array}$ & $\begin{array}{c}\text { B. } \\
\text { chrysantha }\end{array}$ & $\begin{array}{c}\text { Percentage } \\
\text { correct (\%) }\end{array}$ \\
\hline B. gracilis & 26 & 0 & 0 & 0 & 1 & 0 & 96 \\
B. marginata & 1 & 25 & 1 & 0 & 6 & 1 & 74 \\
B. porphyrostele & 0 & 0 & 33 & 4 & 3 & 1 & 80 \\
B. ubatubana & 0 & 0 & 2 & 31 & 4 & 0 & 84 \\
B. picta & 0 & 4 & 5 & 9 & 161 & 1 & 89 \\
B. chrysantha & 0 & 2 & 1 & 0 & 4 & 14 & 67 \\
\hline Total & 27 & 31 & 42 & 44 & 179 & 17 & 85 \\
\hline
\end{tabular}


The patterns observed in the UPGMA dendrogram based on Euclidean distance (data not show) agree with the results of PCA (figure 3) and CVA (figure 4). Specimens of $B$. gracilis grouped together and their cluster are the farthest in relation to the other groups. The remaining species (B. chrysantha, B. marginata, $B$. picta, B. porphyrostele, and $B$. ubatubana) have individuals in many regions of the dendrogram, but tendencies to group together can be seen for all species, as most individuals of each species clustered together. The cophenetic correlation was 0.72 .

\section{Discussion}

Brasiliorchis gracilis has the most evident delimitation among all the examined species, showing a morphological differentiation in all the analyses. Hoehne $(1952,1953)$ accepted six varieties for this species, however there are no evident morphological discontinuities among them, and it is quite impossible to recognize most of them. The small size of most of the characters in B. gracilis can be the reason for this strong differentiation.

Despite the high morphological similarity between B. ubatubana and B. porphyrostele, qualitative characters, like color of sepals and petals (white with red dots in $B$. ubatubana, yellow greenish in $B$. porphyrostele) allow a clear delimitation between them. Moreover, according to Hoehne (1953), these two species rarely happen sympatrically, and the geographical distribution is therefore one of the possible causes of the differentiation between them, as was also observed in some orchid species of the genera Acianthera (Borba et al. 2002) and Pseudorchis (Reinhammar 1998).

The long rhizome of $B$. marginata influenced the morphological diversity found in the performed analyses, since it allows the plant to spread on the tree branches or in flowerpots, when under cultivation: a same clump, originated from a single individual, can have quite different vegetative shapes. This phenotypic plasticity persists in the plants under cultivation, and it can hinder the identification of the species that exhibit individuals overlapping with $B$. picta and B. chrysantha in the analyses.

Brasiliorchis picta and B. chrysantha were the species showing the largest morphological variation, with some of their specimens scattered on PCA and CVA graphs, and individuals clustered with other species. Both have a wide geographical distribution (Hoehne 1953, figure 1) and grow in different habitats: they can be rupicolous, epiphytes or grow on organic matter accumulated over the soil (Hoehne 1953). Extensive geographical distribution can be associated with extensive morphological variation in several genera of Orchidaceae, like Dactylorhiza (Tyteca \& Dufréne 1994), Acianthera (Borba et al. 2002), Pseudorchis (Reinhammar 1998), and Serapias (Pellegrino et al. 2005).

Although they exhibit larger morphologic discontinuities, floral characters played a more important role in the analyses of PCA, CVA and DA than the vegetative ones. Traditionally, floral characters are more used in the taxonomy of the group (Hoehne 1953, Pabst \& Dungs 1977, Butzin \& Senghas 1996); sterile plants are quite impossible to identify. Papers using morphometric methods in the taxonomy of other Orchidaceae genera also evidenced the floral characters as the most informative ones (Reinhammar 1998, Borba et al. 2002, Bernardos et al. 2005).

As all these species grow in similar habitats, sometimes sympatrically, the divergence among them should be maintained by different mechanisms of pollination and/or post-mating barriers that warrant the isolation between species (Borba et al. 2002, Cozzolino et al. 2001, Mant et al. 2005). According to Singer \& Koehler (2004), the species of the B. picta complex and allied genera like Trigonidium and Mormolyca (Singer 2002, Singer et al. 2004) do not offer resources for pollinators and are probably pollinated by deceit. As species pollinated by deceit do not have a high specificity with regard to pollinators, and since introgression and hybridization among sympatric species seem to be a common phenomenon (Soliva \& Widmer 2003, Cozzolino et al. 2006), gene flow may occur between species in the B. picta complex, possibly giving rise to hybrid specimens, which contributes to the morphological overlapping among the species.

Since the use of morphometry may clarify the delimitation of close related species and the relationships of species complexes in Orchidaceae (Reinhammar 1998, Borba et al. 2002, Bernardos et al. 2005, Pellegrino et al. 2005), it is a crucial tool for an objective quantification of biodiversity (Henderson 2005). However, morphometry also has limitations that are evident in several groups of species with probable recent origin, which present an extensive overlapping of morphological characters between species, like the pattern observed in the B. picta complex. In these cases, the use of molecular data, mainly from markers able to reveal a great amount of polymorphisms, is fundamental to understand the species relationships. Works on a population level, using molecular markers like isozymes, AFLP or microsatellites, could identify the evolutionary processes involved in the 
diversification of species complexes, as already evidenced for Dactylorhiza (Pillon et al. 2006), Ophrys (Soliva \& Widmer 2003), Orchis (Cozzolino et al. 2006), and Acianhera (Borba et al. 2002). In these groups, the analysis of a large amount of individuals per population was fundamental to understand the diversification mechanisms of species and lineages, a trend that should be adopted in future works on the B. picta complex.

Acknowledgements - To the staff of the "Seção do Orquidário do Estado" of the Instituto de Botânica, São Paulo, Brazil, for their technical support. This work was supported by a grant from "Fundação de Amparo à Pesquisa do Estado de São Paulo" (Fapesp \# 02/00078-5) to the first author. The second author acknowledges the Brazilian "Conselho Nacional de Desenvolvimento Científico e Tecnológico" for the grant received (CNPq \# 303962/2004-6).

\section{References}

ATWOOD, J.T. \& MORA-DE-RETANA, D.E. 1999. Flora Costaricensis (Orchidaceae). Fieldiana, Botany 40: $1-182$.

BERNARDOS, S., CRESPI, A., DEL REY, F. \& AMICH, F. 2005. The section Pseudophrys (Ophrys, Orchidaceae) in the Iberian Peninsula: a morphological and molecular analysis. Botanical Journal of the Linnean Society 148:359-375.

BORBA, E.L., SHEPHERD, G.J., VAN DEN BERG, C. \& SEMIR, J. 2002. Floral and vegetative morphometrics of five Pleurothallis (Orchidaceae) species: correlation with taxonomy, phylogeny, genetic variability and pollination systems. Annals of Botany 90:219-230.

BUTZIN, F. \& SENGHAS, K. 1996. Subtribus: Maxillariinae. In Rudolf Schlechter, Die Orchideen (F.G. Brieger, R. Maatsch, K. Senghas, eds.). Blackwell, Berlin, p.17271792.

CARNEVALI, G., MUÑOZ, J.L.T. \& GOMEZ-JUAREZ, M. 2001. A synopsis of the Maxillaria rufescens complex in Mexico, Central America, and the Greater Antilles. Brittonia 53:454-465.

COGNIAUX, A. 1904-1906. Orchidaceae. In Flora brasiliensis (C.F.P. Martius, A.G. Eichler \& I. Urban, eds.), v.3, pars 6, p.1-604.

COZZOLINO, S., ACETO, S., CAPUTO, P., WIDMER, A. \& DAFNI, A. 2001. Speciation processes in Eastern Mediterranean Orchis s.l. species: molecular evidence and the role of pollination biology. Israel Journal of Plant Sciences 49:91-103.

COZZOLINO, S., NARDELLA, A.M., IMPAGLIAZZO, S., WIDMER, A. \& LEXER, C. 2006. Hybridization and conservation of Mediterranean orchids: should we protect the orchid hybrids or the orchid hybrid zones? Biological Conservation 129:14-23.
DATHE, S. \& DIETRICH, H. 2006. Comparative molecular and morphological studies in selected Maxillariinae orchids. Willdenowia 36:89-102.

DRESSLER, R.L. 1993. Phylogeny and classification of the orchid family. Dioscorides Press, Portland.

DUNSTERVILLE, G.C.K. \& GARAY, L.A. 1961. Venezuelan Orchids illustrated 2. Andre Deutsch, London.

EVERITT, B.S. 1978. Graphical techniques for multivariate data. North-Holland, New York.

FRONTIER, S. 1976. Study of the decrease of eigenvalues in principal component analysis: comparison with the broken stick model. Journal of Experimental Marine Biology and Ecology 25:67-75.

HENDERSON, A. 2005. The methods of herbarium taxonomy. Systematic Botany 30:456-459.

HOEHNE, F.C. 1952. Espécies e variedades novas de orchidáceas do Brasil. Arquivos de Botânica do Estado de São Paulo 2:121-136.

HOEHNE, F.C. 1953. Orchidaceas. In Flora brasilica (F.C. Hoehne, ed.), v.12, fasc.7, p.1-397.

HOLTZMEIER, M.A., STERN, W.L. \& JUDD, W.S. 1998. Comparative anatomy and systematics of Sengha's cushion species of Maxillaria (Orchidaceae). Botanical Journal of the Linnean Society 127:43-82.

ILLG, R.D. 1977. Revisão taxonômica da secção Heterotaxis (Lindl.) Brieg. do gênero Maxillaria Ruiz \& Pavón. Revista Brasileira de Biologia 37:281-290.

MANT, J., PEAKALL, R. \& SCHIESTL, F.P. 2005. Does selection on floral odour promote differentiation among populations and species of the sexually deceptive orchid genus Ophrys? Evolution 59:1449-1463.

ONISHI, E. 1974. Sobre o polimorfismo do grupo Maxillaria madida (Orchidaceae, Maxillariinae). Tese de doutorado, Universidade Estadual de Campinas, Campinas.

PABST, G.F.J. \& DUNGS, F. 1977. Orchidaceae Brasilienses 2. Kurt Schmersow, Hildesheim.

PELlEGRINO, G., MUSACCHIO, A., NOCE, M.E., PALERMO, A.M. \& WIDMER, A. 2005. Reproductive versus floral isolation among morphologically similar Serapias L. species (Orchidaceae). Journal of Heredity 96:15-23.

PILLON, Y., FAY, M.F., SHIPUNOV, A.B. \& CHASE, M.W. 2006. Species diversity versus phylogenetic diversity: a practical study in the taxonomically difficult genus Dactylorhiza (Orchidaceae). Biological Conservation 129:4-13.

REINHAMMAR, L. 1998. Systematics of Pseudorchis albida s.l. (Orchidaceae) in Europe and North America. Botanical Journal of the Linnean Society 126:363-382.

SHEPHERD, G.J. 2006. FITOPAC 1.6: Manual de usuário. Departamento de Botânica, Universidade Estadual de Campinas, Campinas.

SINGER, R.B. 2002. The pollination mechanism in Trigonidium obtusum Lindl. (Orchidaceae: Maxillariinae): sexual mimicry and trap-flowers. Annals of Botany 89:157-163. 
SINGER, R.B. \& KOEHLER, S. 2004. Pollinarium morphology and floral rewards in Brazilian Maxillariinae (Orchidaceae). Annals of Botany 93:39-51.

SINGER, R.B., FLACH, A., KOEHLER, S., MARSAIOLI, A.J. \& AMARAL, M.C.E. 2004. Sexual mimicry in Mormolyca ringens (Lindl.) Schltr. (Orchidaceae: Maxillariinae). Annals of Botany 93:755-762.

SINGER, R.B., KOEHLER, S. \& CARNEVALI, G. 2007. Brasiliorchis: a new genus for the Maxillaria picta Alliance (Orchidaceae, Maxillariinae). Novon 17:91-99.

SOLIVA, M. \& WIDMER, A. 2003. Gene flow across species boundaries in sympatric, sexually deceptive Ophrys (Orchidaceae) species. Evolution 57:2252-2261.

SZLACHETKO, D.L., MYTNIK-EJSMONT, J., GÓRNIAK, M. \& SMISZEK, M. 2006. Genera et species Orchidalium 15, Maxillarieae. Polish Botanical Journal 15:57-59.
SZLACHETKO, D.L. \& SMISZEK, M. 2007. Nouveaux genres dans le complex Maxillaria (Orchidaceae). Richardiana 7:26-32.

TYTECA, D. \& DUFRÉNE, M. 1994. Biostatistical studies of Western European allogamous populations of the Epipactis helleborine (L.) Crantz species group (Orchidaceae). Systematic Botany 19:424-442.

WHITTEN, M.W., BLANCO, M.A., WILLIAMS, N.H., KOEHLER, S., CARNEVALI, G., SINGER, R.B., ENDARA, L. \& NEUBIG, K.M. 2007. Molecular phylogenetics of Maxillaria and related genera (Orchidaceae: Cymbidieae) based on combined molecular data sets. American Journal of Botany 94:1860-1889.

WILKINSON, L. 2000. Systat Statistics version 10.0 for Windows. SPSS, Chicago. 